\title{
The Relationship Between Disability, Quality of Life and Fear-Avoidance Beliefs in Patients with Chronic Low Back Pain
}

\author{
Kronik Bel Ağrısı Olan Hastalarda Korku Kaçınma Tutumları; Yeti \\ Yitimi ve Yaşam Kalitesi ile İlişkisi
}

Doğan Gucluhan GUCLU ${ }^{1}$, Oya GUCLU², Aysel OZANER ${ }^{3}$, Omer SENORMANCI², Ramazan KONKAN ${ }^{2}$

${ }^{1}$ Bakirkoy Sadi Konuk MD Research and Training Hospital, Department of Neurosurgery, Istanbul, Turkey

${ }^{2}$ Bakirkoy Mental Research and Training Hospital, Department of Psychiatry, Istanbul, Turkey

${ }^{3}$ Lawyer Cengiz Gokcek State Hospital, Department of Psychiatry, Gaziantep, Turkey

Correspondence address: Oya GUCLU / E-mail: oyaguclug@yahoo.com

\begin{abstract}
AIM: The aim of this study is to investigate the relationship between fear and avoidance beliefs with the disability of patients with chronic low back pain and the prediction of quality of life.

MATERIAL and METHODS: 105 outpatients with chronic low back pain were included in the study. Patients were evaluated with a sociodemographic questionnaire Visual Analog Scale Roland Morris Disability Questionnaire Beck anxiety inventory Beck depression inventory, Somatosensory Amplification Scale Fear and avoidance beliefs questionaire and Short form-36 health survey questionnaire.

RESULTS: As pain intensity increased, FABQ increased. Higher levels of anxiety, depression, FABQ (work) leads to higher level of disability. The disability predictors were found to be pain intensity and level of anxiety. When levels of pain intensity, level of anxiety and depression, FABQ increased, physical function decreased. Pain intensity and FABQ (physical) were found to be the predictors of quality of life.

CONCLUSION: Findings of our study were compatible with the previous studies that evaluated the relationship between pain intensity and FAB with the disability of patients with chronic low back pain. We think that it'd have a role for the perception of disability and connected to this to prevent the impairment of life quality by implications for FAB in these patients.
\end{abstract}

KEYWORDS: Chronic low back pain, Fear and avoidance beliefs, Disability, Quality of life

öz

AMAÇ: Çalışmamızın amacı, kronik bel ağrısı olan hastalarda korku kaçınma inançlarının yeti yitimi ile ilişkisinin ve yaşam kalitesindeki yordayıcılığının değerlendirilmesidir.

YÖNTEM ve GEREÇLER: Çalışmaya kronik bel ağrısı yakınması ile başvuran 105 hasta dahil edildi. Katılımcılar sosyodemografik veri formu, Görsel Analog Skala Roland Morris Yetiyitimi anketi, Beck Anksiyete Envanteri, Beck Depresyon Envanteri, Bedensel duyumları abartma ölçeği, Korku kaçınma tutumları anketi ve Kısa form-36 ile değerlendirildi.

BULGULAR: Ağrı şiddeti arttıkça korku kaçınma artmaktaydı. Depresyon anksiyete ve korku kaçınma (mesleki) düzeyindeki artış yetiyitiminin artmasına yol açmaktaydı. Ağrı şiddeti ve anksiyete düzeyi yeti yitiminin yordayıcıları olarak belirlendi. Ağrı şiddeti anksiyete ve depresyon düzeyleri korku kaçınma arttıkça fiziksel fonksiyon azalmaktaydı. Ağrı şiddeti ve fiziksel korku kaçınma tutumları fiziksel işlevselliğin yordayıcıları olarak bulundu.

SONUÇ: Çalışmamızın bulguları kronik bel ağrılı hastalarda ağı şiddetinin ve korku kaçınma inançlarının yeti yitimi ile ilişkisinin değerlendirildiği önceki çalışmalarla uyumlu bulunmuştur. Bu hastalarda korku kaçınma inançlarının değerlendirilmesinin yeti yitimini anlama ve buna bağlı yaşam kalitesindeki bozulmanın önlenmesinde rol oynayabileceğini düşünmekteyiz.

ANAHTAR SÖZCÜKLER: Kronik bel ağrısı, Korku kaçınma tutumları, Yeti yitimi, Yaşam kalitesi

\section{INTRODUCTION}

Four components of pain have been described as somatic, emotional, cognitive and behavioral (27). It was stressed that perception of pain and reactions to pain are specific to person. It is accepted that differences in the endurance of people to pain is reflected to their quality of life (23).
In 'gate control theory' proposed by Melzack R and Wall PD in 1965 , it was suggested that cognitive mechanisms in the brain are an indispensable part of the phenomenon of pain. It was revealed that previously learned behavior and information is important in the perception of pain (25). 
Biophysicosocial model developed by Loeser in 1982 draw attention to importance of the values ascribed to painful stimulus (22). It was reported that the value ascribed to the stimulus is influenced from life long beliefs of the person and is shaped by his/her emotional reactions. It is posssible for the person to disregard the pain and continue his work and socialization and maintain his previous activity level while it is also possible that he/she can quit working, avoid all physical activities and assume the role of the patient. Thus, these factors lead to the formation of chronic pain and disability.

In various studies, it was underlined that even when the factor causing pain is eliminated, impairment in functionality may continue, which raises the question whether other variables also affect functionality independent of the level of pain. In studies investigating the impact of pain and associated factors, it was established that anxiety and depression enhanced the perception of pain (34).

Sometimes, a fear based condition may arise in order to be protected from the perceived threat of disaster as a results of beliefs regarding pain. Anxiety developing related to pain is associated with excessive sensitivity to being harmed, excessive arousal and ultimately avoidance behavior and is focused on the future (8).

In low back pain problems, the term 'fear avoidance' was used to refer to fear from pain or movement associated with expectations concerining the consequence of activities. Pain related fear is defined as the development of sensitivity state towards injury that may cause pain and disproportionate and exaggarated fear of physical movement that makes one feel helpless (29). It has been accepted that fear or pain leads one to restrict his/her own movements. It was suggested that evaluation of pain by people affect the level of fear that may develop and hence the behavior of avoidance of movement $(1,12,16)$.

A strong relation was shown between low back pain and fear avoidance behavior $(6,19)$. For patients with low back pain, it was suggested that beliefs related to fear and avoidance are the major determinant of disability. It was found that fear and avoidance beliefs account for $32 \%$ of disability and $14 \%$ of the severity of pain (33).

The aim of the present study was to evaluate the fear and avoidance beliefs in patients referring with chronic low back pain and to examine the determinants of the disability and the predictors of quality of life in that group.

\section{MATERIAL and METHODS}

\section{Study design and sample}

105 literate patients between the ages of 18-66 who referred to neurosurgery outpatient clinic of Bakırköy Dr. Sadi Konuk Training and Investigation Hospital with the complaint of chronic low back pain within the last three months were included in the study. Following the approval of ethics committee, patients from whom infromed consent was obtained were consecutively enrolled in the study. Those who have clinical mental retardation, dementia or other organic mental disorders were excluded.

\section{Evaluation tools}

In order to evaluate the sociodemographic and clinical characterics of the participants, sociodemogaphic data form developed by the investigators was administered. Severity of pain was measured with Visual Analog Scale (VAS). For measuring disability Roland Morris Disability questionnaire was administered. Participants were evaluated with Beck Anxiety Inventory, Beck Depression Inventory, Somatosensory Amplification Scale and Fear and Avoidance Beliefs Questinnaire (FABQ). In order to evaluate the quality of life, short form-36 was used.

Sociodemographic Data Form: It was developed by the investigators to evaluate sociodemographic characteristics such as age, sex, education status, marital status, work and social status and clinical characteristics such as regions of pain and duration of pain.

Visual analog sclae (VAS): It is a $10 \mathrm{~cm}$ rule. One end signifies most severe pain and the other end signifies no pain. The distance from no pain to where the patient has made his/ her mark reflects the pain of the patient. It was developed by Price et al. in 1983 (28).

Beck Anxiety Inventory: It is a Likert type self evaluation scale containing 21 articles. High overall score indicates high level of anxiety. It was developed by Beck et al in 1988 (3), and its reliability and validity study in Turkey was carried out by Ulusoy et al. in 1988 (35).

Beck Depression Inventory: It was developed to determine the risk of depression in the individual and to measure the severity of depressive symptoms and the change in severity. Its original form was developed by Beck et al. (4) Its reliability and validity study in Turkey was carried out by Hisli in 1988 (15).

Somatosensory Amplification Scale: It is a 10 article scale developed by Barsky et al. (2) It is a Likert type self evaluation scale. Many articles include a number of disturbing physical sensations not indicating a disease. With the addition of scores from articles, an overall amplification score is obtained. Its reliability and validity study in Turkey was carried out by Sayar et al. in 2003 (3).

Fear and Avoidence Belief Questionnary: (FABQ) It was developed by Waddell et al. in 1993 (38). All includes 16 questions and 2 parts. First part of the questionnaire evaluates the attitude towards physical activities and the second part attitudes towards professional work activities. It is a 7 Likert type scale and physical activity part is scored between 0-24 and work part between 0-36. Its reliability and validity study in Turkey was carried out by Korkmaz et al. in 2006 (18).

Roland Morris Disability Questionnare: It is a questionnaire of 24 questions developed by Roland and Morris in 1983 to evaluate the functional impairment (30). It is answered as yes 
or no and over all score is found according to number of yes answers. Its reliability and validity study in Turkey was carried out by Küçükdeveci et al. in 2001 (21).

Short Form (SF-36): It was developed by John E. Ware and Sherbourne CD (SF-36) in 1992 (38). It is the most commonly used scale in the measurement of the quality of life. It was developed to measure quality of life particularly in people with physical disease. Its scoring requires detailed instructions. The calculation of scores from scales necessitates a number of calculations. There is no overall score. Overall score of 8 scales, i.e. physical functioning, social functioning, role-physical, role-emotional, mental health, vitality, bodily pain, and general health perception is calculated. Its reliability and validity study in Turkey was carried out by Kocyigit et al. in 1999 (17).

Statistical Evaluation: In the evaluation of the findings of the study SPSS 16 for Windows was used for statistical analysis. In the evaluation of data, in addition to descriptive statistical methods, (Frequency, percentage, mean, Standard deviation), for the examination of normal distribution Kolmogorov - Smirnov distribution test was used. In the comparison of quantitative data, in two groups, in the intragroup comparison of normally distributed parameters (Independent samples) t test was used. In order to determine the relation between scales, Pearson Correlation Analysis was used. Significance was evaluated at $p<0.05$ and $p<0.01$ levels. Logistic regression analysis was carried out.

\section{RESULTS}

\section{Sociodemographic characteristics}

Study included overall 105 patients, 69 of whom was (\%65.7) female and 36 of whom (\%34.3) male. Their ages ranged between $18-66$ with a mean age of $37.50 \pm 12.19$. $\% 43.8$ of the patients stated that they experienced problems in their work life related to health while \%49.5 stated that they experienced problems in their social lives related to health within the last 6 months. Sociodemographic characteristics of the patients is shown in Table I. Their scale scores are outlined in Table II.

Table I: Sociodemographic Characteristics of the Patients

\begin{tabular}{|c|c|c|c|}
\hline & & $\mathbf{n}$ & $\%$ \\
\hline \multirow{2}{*}{ Sex } & Male & 36 & 34,3 \\
\hline & Female & 69 & 65,7 \\
\hline \multirow{2}{*}{ Marital status } & Married & 80 & 76,2 \\
\hline & Single & 25 & 23,8 \\
\hline \multirow{4}{*}{ The number of pregnancies } & 1 & 8 & 14,0 \\
\hline & 2 & 19 & 33,3 \\
\hline & 3 & 17 & 29,8 \\
\hline & 4 or over & 13 & 22,8 \\
\hline \multirow{5}{*}{ Smoking status } & Does not smoke & 81 & 77,1 \\
\hline & 10 & 16 & 15,2 \\
\hline & $10-20$ & 3 & 2,9 \\
\hline & $20-30$ & 4 & 3,8 \\
\hline & $30-40$ & 1 & 1,0 \\
\hline \multirow{4}{*}{ Education level } & Primary school & 57 & 54,3 \\
\hline & Secondary school & 20 & 19,0 \\
\hline & High school & 21 & 20,0 \\
\hline & University & 7 & 6,7 \\
\hline \multirow{5}{*}{ Occupation } & Job requiring physical activity & 35 & 33,3 \\
\hline & Job not requiring physical activity & 15 & 14,3 \\
\hline & unemployed & 8 & 7,6 \\
\hline & Retired & 5 & 4,8 \\
\hline & House wife & 42 & 40,0 \\
\hline \multirow{2}{*}{ Trauma experience } & Present & 7 & 6,7 \\
\hline & Absent & 98 & 93,3 \\
\hline
\end{tabular}


Table II: Scores Obtained by Patients from the Scales

\begin{tabular}{|c|c|c|c|c|}
\hline & mean & S.D. & Min. & Max. \\
\hline Beck anxiety & 16,84 & 12,65 & 0 & 54 \\
\hline Beck depression & 16,06 & 10,74 & 0 & 48 \\
\hline VAS & 62,21 & 22,11 & 5 & 100 \\
\hline Roland Morris & 15,43 & 6,05 & 0 & 24 \\
\hline Fear avoidance (physical) & 14,57 & 6,25 & 0 & 24 \\
\hline Fear avoidance (work) & 15,19 & 9,69 & 0 & 36 \\
\hline Fear avoidance (overall) & 29,47 & 13,44 & 0 & 60 \\
\hline
\end{tabular}

\section{Clinical Characteristics}

a. Findings related to pain; The duration of pain was significantly longer in female patients than male patients $(t=-$ 2.13; $p=0.035$ ) Duration of pain was shorter in the patients in 18-30 age group than that in $31-44$ age group ( $F=3.547$; $p=0.032$ ). No significant relation was found between fearavoidance and duration of pain ( $p>0.05)$.

Correlation analysis made so as to determine the relation between the severity of pain evaluated with VAS and fearavoidance (physical) found weakly positive significant relation between them. Again, a weakly positive significant relation was found between VAS scores and fear-avoidance (work) and (overall). According to these results, as severity of pain increased, fear-avoidance (physical, work, overall) increased as well.

\section{b. Findings Related to Disability}

Mean score of disability found with Roland Morris was 15.43 \pm 6.05 . Mean scores were found to be significantly higher in married patients than single patients $(t=3.17 ; p=0.002)$.

There was weak-moderate positive relation between Roland Morris disability and Beck anxiety scores and very weak positive relation with Beck depression scores. According to these results, disability increased as depression and anxiety levels increased.

No significant relation was found between disability and fear avoidance (physical) ( $p>0.05$ ), while weak-moderate posivie relation was found with fear-avoidance (work) and (overall). According to these results, disability increased as fearavoidance (work and overall) increased.

In the logistic regression model used, severity of pain measured with VAS and Beck anxiety scores explained Roland Morris disability score at the rate of $0.203\left(R^{2}=0.203\right)$. When the severity of pain increased one unit, disability increased 0.080 units $(\beta=0.080 ; t=2.988 ; p=0.004)$. When anxiety level increased one unit, disability increased 0.123 units

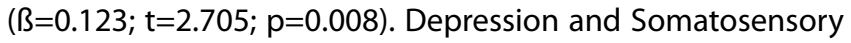
Amplification scores had significant effect on disability (Table III).

\section{c. Findings related to quality of life}

According to the evaluation made with SF-36 ile; mean physical function was $46.67 \pm 22.97$ (0-90), mean social function $58.97 \pm 18.53$ (22-89), mean role function (physical) $31.90 \pm 35.78(0-100)$, mean role function (emotional) 45.60 \pm 33.19 (0-100), mental mean health I $58.13 \pm 14.33(28-96)$, mean vitality/fatigue $70.95 \pm 13.68$ (40-100), mean pain 55.64 \pm 20.61 (33-100), mean general health $60.52 \pm 14.89$ (30-100), and mean change within the last year $74.05 \pm 17.99$ (26-100).

\section{Physical function}

A weak-moderate negative relation was found between VAS and physical function. Accordingly, as the severity of pain increased physical function decreased. There was weakmoderate significant negative relation between Beck anxiety and depression scores and physical function. This indicated that as anxiety and depression levels increased, physical function decreased.

According to correlation analysis made to determine the relation between fear-avoidance (physical) and physical function, weak-moderate negative significant relation was found between scores. A weak-moderate negative significant relation was found between fear-avoidance (work) and physical function as well. Accordingly, as fear-avoidance increased (physical, work) physical function decreased.

\section{Role function (physical)}

According to correlation analysis made to determine the relation between VAS and role function (physical) a weakmoderate significantly negative relation was found between them. Namely, role function (physical) decreased as severity of pain increased.

A weak-moderate significantly negative relation was found between beck anxiety scores and role function (physical) Accordingly, as anxiety level increased, role function (physical) decreased.

Very weak negative significant relation was found between fear-avoidance behavior (overall) and role function (physical). Accordingly, as fear-avoidance(overall) increased, role function (physical) decreased.

\section{Role function (Emotional)}

According to correlation analysis made to determine the relation between Beck anxiety scores and role function (emotional) very weak significantly negative relation was 
found between them. Accordingly, as anxiety level increased, role function (emotional) decreased.

Correlation analysis was made to determine the relation between fear-avoidance (physical) and role function (emotional) and it was found that there was weakly negative relation with fear avoidance (physical) and weak-moderate negative significant relation with fear-avoidance behavior (overall). Accordingly, as fear-avoidance (physical, work, overall) increased, role function(emotional) decreased (Table IV).

Table III: Disability Predictors

\begin{tabular}{|c|c|c|c|c|c|c|c|}
\hline $\begin{array}{l}\text { Dependent } \\
\text { variable }\end{array}$ & $\begin{array}{l}\text { Independent } \\
\text { variable }\end{array}$ & $\beta$ & $\mathbf{t}$ & $\mathbf{P}$ & $\mathbf{F}$ & $\begin{array}{l}\text { Model } \\
\text { (p) }\end{array}$ & $\mathbf{R}^{2}$ \\
\hline \multirow{3}{*}{ Roland Morris } & Constant & 8,552 & 5,241 & 0,000 & \multirow{3}{*}{13,062} & \multirow{3}{*}{0,000} & \multirow{3}{*}{0,203} \\
\hline & VAS & 0,080 & 2,988 & $0,004^{* *}$ & & & \\
\hline & Beck anxiety & 0,123 & 2,705 & $0,008^{* *}$ & & & \\
\hline
\end{tabular}

Table IV: Findings on Quality of Life

\begin{tabular}{|c|c|c|c|c|c|c|c|}
\hline & & VAS & Beck anxiety & $\begin{array}{c}\text { Beck } \\
\text { depression }\end{array}$ & $\begin{array}{c}\text { fear - } \\
\text { avoidance } \\
\text { (physical) }\end{array}$ & $\begin{array}{c}\text { fear - } \\
\text { avoidance } \\
\text { (work ) }\end{array}$ & $\begin{array}{c}\text { fear - } \\
\text { avoidance } \\
\text { (overall) }\end{array}$ \\
\hline \multirow{3}{*}{$\begin{array}{l}\text { Physical } \\
\text { functioning }\end{array}$} & $r$ & $-0,477$ & $-0,293$ & $-0,256$ & $-0,294$ & $-0,291$ & $-0,36$ \\
\hline & $p$ & $0,000^{* *}$ & $0,003^{* *}$ & $0,008^{* *}$ & $0,003^{* *}$ & $0,003^{* *}$ & $0,000^{* *}$ \\
\hline & $\mathrm{N}$ & 100 & 104 & 105 & 103 & 101 & 103 \\
\hline \multirow{3}{*}{$\begin{array}{l}\text { Social } \\
\text { functioning }\end{array}$} & $r$ & $-0,083$ & $-0,116$ & $-0,137$ & $-0,18$ & $-0,033$ & $-0,09$ \\
\hline & $p$ & 0,413 & 0,241 & 0,163 & 0,069 & 0,74 & 0,368 \\
\hline & $\mathrm{N}$ & 100 & 104 & 105 & 103 & 101 & 103 \\
\hline \multirow{3}{*}{$\begin{array}{l}\text { Role function } \\
\text { (Physical) }\end{array}$} & $r$ & $-0,277$ & $-0,299$ & $-0,167$ & $-0,178$ & $-0,17$ & $-0,199$ \\
\hline & $p$ & $0,005^{* *}$ & $0,002^{* *}$ & 0,088 & 0,072 & 0,09 & $0,044^{*}$ \\
\hline & $\mathrm{N}$ & 100 & 104 & 105 & 103 & 101 & 103 \\
\hline \multirow{3}{*}{$\begin{array}{l}\text { Role function } \\
\text { (Emotional) }\end{array}$} & $r$ & $-0,19$ & $-0,232$ & $-0,176$ & $-0,228$ & $-0,289$ & $-0,303$ \\
\hline & $\mathrm{p}$ & 0,058 & $0,018^{*}$ & 0,073 & $0,021^{*}$ & $0,003^{* *}$ & $0,002^{* *}$ \\
\hline & $\mathrm{N}$ & 100 & 104 & 105 & 103 & 101 & 103 \\
\hline \multirow{3}{*}{ Mental health } & $r$ & 0,305 & 0,42 & 0,522 & 0,111 & 0,156 & 0,171 \\
\hline & $p$ & $0,002^{* *}$ & $0,000^{* *}$ & $0,000^{* *}$ & 0,263 & 0,12 & 0,084 \\
\hline & $\mathrm{N}$ & 100 & 104 & 105 & 103 & 101 & 103 \\
\hline \multirow{3}{*}{ Fatique/Vitality } & $r$ & 0,304 & 0,219 & 0,355 & $-0,026$ & 0,177 & 0,095 \\
\hline & $\mathrm{p}$ & $0,002^{* *}$ & $0,026^{*}$ & $0,000^{* *}$ & 0,793 & 0,076 & 0,341 \\
\hline & $N$ & 100 & 104 & 105 & 103 & 101 & 103 \\
\hline \multirow{3}{*}{ Pain } & $r$ & 0,214 & 0,257 & 0,094 & $-0,024$ & 0,108 & 0,079 \\
\hline & $\mathrm{p}$ & $0,033^{*}$ & $0,009^{* *}$ & 0,342 & 0,809 & 0,283 & 0,43 \\
\hline & $\mathrm{N}$ & 100 & 104 & 105 & 103 & 101 & 103 \\
\hline \multirow{3}{*}{ General health } & $r$ & $-0,001$ & 0,045 & $-0,053$ & $-0,066$ & 0,02 & 0 \\
\hline & $\mathrm{p}$ & 0,993 & 0,649 & 0,589 & 0,511 & 0,844 & 0,997 \\
\hline & $\mathrm{N}$ & 100 & 104 & 105 & 103 & 101 & 103 \\
\hline \multirow{3}{*}{$\begin{array}{l}\text { Change within } \\
\text { the last year }\end{array}$} & $r$ & 0,063 & 0,164 & 0,127 & $-0,107$ & 0,2 & 0,089 \\
\hline & $p$ & 0,531 & 0,096 & 0,196 & 0,281 & $0,045^{*}$ & 0,374 \\
\hline & $\mathrm{N}$ & 100 & 104 & 105 & 103 & 101 & 103 \\
\hline
\end{tabular}

${ }^{*} p<0,05,{ }^{* *} p<0,01$. 


\section{d. Predictors of physical function}

Regression model used to tests the effect of independent variables on physical function yielded significant results $(F=16.722 ; p=0.000)$.Severity of pain and fear-avoidance (physical) accounted for physical functionality at the rate of $0.251\left(R^{2}=0.251\right)$.

When the severity of pain increased one unit, physical function decreased $-0,462$ unit ( $\beta=-0.462 ; t=-4.703 ; p=0.000$ ) and when fear-avoidance (physical) increased one unit, physical function decreased $-0,747$ units $(B=-0.747 ; t=-2.129$; $\mathrm{p}=0.036$ ). Fear-avoidance (work), level of somatosensory amplification, duration of pain, anxiety and depression levels had no significanty effect on physical function (Table V).

\section{DISCUSSION}

In the present study, duration of pain was found to be significantly longer in female patients than male patients, while there was no difference between female and male patients in terms of the severity of pain. However, disability was observed at a higher rate in female patients. These results may be explained by weaker paraspinal support muscles in women or concentration of support system in iliac system or hormonal cycles (26) as well as later referral of female patients for treatment.

Duration of pain was significantly shorter in the 18-30 age group. In addition, mean disability scores in the patients were found to be significantly lower than that in the patients who are 31-44 years old or 45 or older. It was thought that earlier referral of younger patients for treatment and hence earlier onset of treatment process may result in relief of symptoms and their being more active physically and socially and less disability.

In the present study, a weakly positive relation was found betwen the severity of pain and fear and avoidance (physical, work, overall). Fritz et al reported a moderately significant relation between severity of acute pain and fear and avoidance (9) and George et al found in their patient group with chronic lower back pain a moderately significant relation between the severity of pain and fear and avoidance behavior (11).

In the present study, as the severity of pain increased, so did fear and avoidance behavior. Severity of pain is determined subjectively by the patient, suggesting that fear and avoidance behavior may enhance pain perception. Yet, no statistically significant relation was found between duration of pain and fear-avoidance.
In the present study, while no statistically significant relation was found between disability and fear-avoidance (physical), as fear-avoidance (work and overal) increased, disability increased as well. Avoidance behavior is a negative cognitive structuring and since its not a functional defense mechanism against pain, the correlation between disability and avoidance is an expected result.

In the study of Crombez et al, a moderately significant relation was found between physical and work fear-avoidance behavior and disability (7). Sions and Higs explained the lack of a significant relation between fear avoidance and disability in their Hispanic patients, which is similar to our results, with the occurrence of fear and avoidance in the context of the severity of pain and external control focus in these patients (32). In the study of Cai et al. (5) which they cited, it was stressed that severity of pain partly mediated the relation between fear avoidance behavior and disability. They emphasized the need for studies evaluating ethnic characteristics with respect to their mediator role in the severity of pain.

Hicks et al stated that fear and avoidance behavior in work is a highly specific finding for disability (14) and George et al demonstrated that in patients with chronic low back pain, the single predictor of disability was fear avoidance behavior (work) (10). In the present study, regression model used to determine the predictors of disability, only level of anxiety and severity of pain were found to have a significant effect. As to the study of Waddell et al, severity of pain and fear avoidance behavior were found to be predictors of disability (38).

In patients with chronic low back pain, fear related to pain is associated with the impairment of physical performance (36) and has been reported to increase self reported disability (1). Especially in patients with active work life, fear and avoidance behavior was found to be directly correlated to work loss related to chronic lower back pain (9). Mewisse-Swinkels et al reported that in the patient group without active work life, no significant relation was present between fear and avoidance behavior and severity of pain (24).

In the present study, fear and avoidance (physical) mean (SD) values were 14.57(6.25) while fear avoidance behavior (work) mean(SD) values were 15.19 (9.69), which was similar to those found in previous studies (24).

In the present study, $43.8 \%$ of the patients stated that they experienced problems in their work life due to health and $49.5 \%$ stated that they had difficulties in social life related to health. In the present study, as severity of pain and fearavoidance behavior increased, physical function decreased. In

Table V: Physical Function Predictors

\begin{tabular}{|l|l|c|c|c|c|c|c|}
\hline Dependent variable & Independent variable & $\boldsymbol{B}$ & $\mathbf{t}$ & $\mathbf{p}$ & $\mathbf{F}$ & Model (p) \\
\hline Physical function & Constant & 85,448 & 11,822 & 0 & 16,722 & 0 \\
& VAS & $-0,462$ & $-4,703$ & 0 & & 0,251 \\
\hline & Fear avoidance- physical - & $-0,747$ & $-2,129$ & 0,036 & & \\
\hline
\end{tabular}


the study of Kovascs et al., a correlation between severity of pain, the level of disability and quality of life was reported (20). Likewise, Sengul et al. found a correlation between severity of pain and quality of life. It was reported that negative beliefs decreased quality of life in patients. In the chronic status of lower back pain, quality of life is evaluated as a functional characteristic and anxiety, depression and negative beliefs as emotional factors (31).

In the present study, in regression model used to determine the predictors of physical function, severity of pain and fear-avoidance behavior (physical) accounted for physical functionality at the rate of 0.251 . However, fear-avoidance behavior (work), somatosensory amplification level, duration of pain, anxiety and depression levels were not found to be predictors of physical function.

One of the limitations of our study is that there was no injury related to work specifically and it was not inquired the degree to which present work life required physical power. Especially in patients with high fear- avoidance behavior (work), studies evaluating the effect of work characteristics on disability and quality of life should be planned. As the present study is a cross sectional one, it does not yield information regarding cause- effect relations. It will be better to demonstrate the effect of fear and avoidance behavior on the course of disease by means of prospective follow up studies.

It was demonstrated that decreasing pain related fear through cognitive behavioral treatment methods resulted in increase in endurance to activity and functional capacity (37). It is thought that further studies which will determine the cutoff points for severity of pain and fear avoidance behavior as markers for preventing the decrease in quality of life will be beneficial in this respect.

\section{REFERENCES}

1. Asmundson GJ, Norton PJ, Vlaeyen JW: Fear-avoidance models of chronic pain: An overview. Asmundson GJ, Vlaeyen JW, Crombez G (eds), Understanding and Treating Fear of Pain, New York: Oxford University Press, 2004: 3-24

2. Barsky AJ, Wyshak G, Klerman GL: The somatosensory amplification scale and its relationship to hypochondriasis. J Psychiatr Res 24:323-334, 1990

3. Beck AT, Epstein N, Brown G, Steer RA: An inventory for measuring clinical anxiety: Psychometric properties. J Consult Clin Psychol 56:893-897, 1988

4. Beck AT, Ward CH, Mendelson M, Mock J, Erbaugh J: An inventory for measuring depression. Arch Gen Psychiatry 4:561-571, 1961

5. Cai C, Pua YH, Lim KC: Correlates of self reported disability in patients with low back pain: The role of fear avoidance beliefs. Ann Acad Med Singapure 36:1013-1020, 2007
6. Chaory K, Rannou F, Fermanian J, Genty M, Rosenberg S, Billabert C, Kemoun G, Richard I, Thevenon A, Coudeyre $L$, Sender J, Revel M, Poiraudeau S: Impact of functional restoration programs on fears, avoidance and beliefs in chronic low back pain patients. Ann Readapt Med Phys 47: 93-97, 2004

7. Crombez G,Vlaeyen JW, Heuts PH, Lysens R: Pain related fear is more disabling than pain itself: Evidence on the role of pain related fear in chronic back pain disability. Pain 80:329-339, 1999

8. Davey GC: Classical conditioning and the acquisition of human fears and phobias: A review and synthesis of the literature. Adv Behav Res Ther 14:29-66, 1992

9. Fritz JM, George SZ: Identifying psychosocial variables in patients with acute work related low back pain: The importance of fear-avoidance beliefs. Phys Ther 82:973-983, 2002

10. George SZ, Fritz JM, Childs JD: Investigation of elevated fear avoidance beliefs for patients with low back pain: A secondary analysis involving patients enrolled in physical therapy clinical trials. J Orthop Sports Phy Ther 38:50-58, 2008

11. George SZ, Fritz JM, Erhard RE: A comparison of fear avoidance beliefs in patients with lumbar spine pain and cervicalspine pain. Spine 26:2139-2145, 2001

12. Goubert L, Crombez G, Peters M: Pain-related fear and avoidance: A conditioning perspective. Asmundson GJ, Vlaeyen JW, Crombez G (eds), Understanding and Treating Fear of Pain. New York: Oxford University Press, 2004: 25-50

13. Gulec $\mathrm{H}$, Sayar K: Reliability and validity of the Turkish form of the Somatosensory Amplification Scale. Psychiatry Clin Neurosci 61:25-30, 2007

14. Hicks GE, Fritz JM, Delitto A, Mc Gill SM: Preliminary development of a clinical prediction rule for determining which patients with low back pain will respond to a stabilization exercise program. Arch Phys Med Rehabil 86:1753-1762, 2005

15. Hisli N: Reability and validity of Beck Depression Inventory among university students. J Turk Psychol 7:3-13, 1989

16. Jellema $P$, van der Windt $D A$, van der Horst $H E$, Blankenstein $\mathrm{AH}$, Bouter LM, Stalman WA: Why is a treatment aimed at psychosocial factors not effective in patients with (sub)acute low back pain? Pain 118:350-359, 2005

17. Kocyigit $H$, Aydemir O, Fisek G, Olmez N, Memis A: Kısa form36'nın Türkçe versiyonunun güvenilirliği ve geçerliliği. İlaç ve Tedavi Dergisi 12:102-106, 1999

18. Korkmaz N, Akinci A, Surucu SH, Saracbasi O, Ozcakar L: Validation and reliability of the Turkish version of the fear avoidance beliefs questionnaire in patients with low back pain. Eur J Phys Rehabil Med 45:527-535, 2009

19. Kovacs FM, Muriel A, Medina JM, Abraira V, Sánchez MD, Jaúregui JO: Psychometric characteristics of the Spanish version of the FAB Questionnaire. Spine 31:104-110, 2006

20. Kovascs FM, Abraira V, Zamora J, Fernandez C: The transition from acute to subacute and chronic low back pain: A study based on determinants of quality of life and prediction of chronic disability. Spine 30:1786-1792, 2005 
21. Kucukdeveci AA, Tennant A, Elhan AH, Niyazoglu H: Validation of the Turkish version of the Roland-Morris Disability Questionnaire for use in low back pain. Spine 26:2738-2743, 2001

22. Loeser JD: Perspectives on pain. Tuner P (ed), Clin Pharm Ther, London: Macmillan Press, 1982: 313-316

23. Lyons RA, Lo SV, Littlepage BNC: Comparative health status of patients with 11 common illnesses in Wales. J Epidemiol Community Health 48:388-390, 1994

24. Swinkels-Meewisse IE, Roelofs J, Verbeek AL, Oostendorp RA, Vlaeyen JW: Fear-avoidance beliefs, disability and participation in workers and nonworkers with acute low back pain. Clin J Pain 22:45-54, 2006

25. Melzack R, Wall PD: Pain mechanisms: A new theory. Science 19:971-979, 1965

26. Miller EM, Slota GP, Agnew MJ, Madigan ML: Females exhibit shorter paraspinal reflex latencies than males in response to sudden trunk flexion perturbations. Clin Biomech 25: 541-545, 2010

27. Ozkan S: Ağrılı hastaya psikiyatrik yaklaşım. PsychoMed 1: 49-54, 1995

28. Price DD, McGrath PA, Rafii A, Buckingham B: The validation of visual analogue scales as ratio scale measures for chronic and experimental pain. Pain 17:45-56, 1983

29. Reneman MF, Schiphorts Preuper HR, Kleen M, Geertzen JHB, Dijkstra PU: Are pain intensity and pain related fear related to functional capacity evaluation performances of patients with chronic low back pain. J Occup Rehabil 17:247-258, 2007

30. Roland M, Morris R: A study of the natural history of back pain. Part l: development of a reliable and sensitive measure of disability in low-back pain. Spine 8:141-144, 1983
31. Sengul Y, Kara B, Arda MN: The relationship between health locus of control and quality of life in patients with chronic low back pain. Turkish Neurosurgery 20:180-185, 2010

32. Sions JM, Hicks GE: Fear avoidance beliefs are associated with disability in older American adults with low back pain. Phys Ther 91:525-534, 2011

33. Staerkle R, Mannion AF, Elfering A, Junge A, Semmer NK, Jacobshagen N, Grob D, Dvorak J, Boos N: Longitudinal validation of the fear-avoidance beliefs questionnaire (FABQ) in a Swiss-German sample of low back pain patients. Eur Spine J 13:332-340, 2004

34. Turk DC: Psychological factors in chronic pain: Evolution and revolution. J Cons Clin Psyco 70:678-690, 2002

35. Ulusoy $M$, Erkmen $H$, Sahin N: Turkish version of the Beck Anxiety Inventory: Psychometric properties. J Cog Psychother 12:163-172, 1998

36. Van den Hout JHC, Vlaeyen JWS, Heuts PHTG, Sillen WJT, Willen AJEHL: Functional disability in nonspecific low back pain: The role of pain-related fear and problem-solving skills. Int J Behav Med 8:134-138, 2001

37. Vlaeyen JW, De Jong JR, Onghena P, Kerckhoffs-Hanssen $M$, Kole-Snijders AM: Can pain related fear be reduces? The application of cognitive behavioural exposure in vivo. Pain Res Manag 7:144-153, 2002

38. Waddell G, Newton M, Henderson I, Somerville D, Main CJ: A fear-avoidance beliefs questionnaire (FABQ) and the role of fear-avoidance beliefs in chronic low back pain and disability. Pain 52:157-168, 1993

39. Ware JE, Sherbourne CD: The MOS 36 item short form health survey (SF 36) Conceptual framework and item selection. Med Care 30:473-483, 1992 